\title{
Polis y Dêmos. Una reflexión sobre la democracia griega antigua*
}

Recibido: 12/02/2021 | Revisado: 03/08/2021 | Aceptado: 20/08/2021

DOI: 10.17230/co-herencia.18.35.11

\section{Mauricio Vélez Upegui**}

mavelez@eafit.edu.co

\begin{abstract}
Resumen Numerosas son las creaciones culturales que los griegos de la Antigüedad, y más puntualmente los atenienses, se dieron a sí mismos. Una de ellas, relacionada con la institución de la vida social, fue la democracia, entendida, en términos etimológicos, como "poder del pueblo". En otro sentido, la democracia puede ser descrita como un tipo de régimen político, o, si se quiere, como una forma de organizar los poderes públicos de una ciudad. Tal idea se desprende del breve tratado aristotélico, descubierto en Egipto hace más de un siglo, conocido como Constitución de los atenienses. Apoyándonos en este tratado y estableciendo algunas relaciones con otras fuentes antiguas y modernas, el propósito de este escrito es adelantar una reflexión sobre la democracia ática antigua, con el fin de señalar que tres, entre otros, son los fundamentos de dicha forma de gobierno: la autonomía, la participación y el "control" políticos.
\end{abstract}

\section{Palabras clave:}

Atenas, autonomía, ciudad, control, participación, régimen político, Aristóteles.

\section{Polis and Dêmos. A reflection on ancient Greek democracy}

\footnotetext{
Abstract There are numerous cultural creations that the Greeks of Antiquity, and more specifically the Athenians, gave to themselves. One of them, related to the institution of social life, was democracy, understood in etymological terms as "power of the people." In another sense, democracy can be described as a type of political system, or as a way of organizing the public powers of a city. Such an idea is derived from the brief Aristotelian treatise, discovered in Egypt more than a century ago, known as the Constitution of the Athenians. Relying on this treatise and establishing some relationships with other ancient
}

* Este trabajo es resultado de la investigación titulada Acerca de la hospitalidad en Homero (un análisis narratológicohermenéutico), Grupo: Estudios en filosofía, hermenéutica y narrativas (Categoría A1 de Colciencias). Departamento de Humanidades, Universidad EAFIT, Medellín-Colombia.

** Magíster en Literatura Colombiana. Profesor asistente de la Escuela de Humanidades de la Universidad EAFIT, Medellín-Colombia. ORCID: 0000-00029359-7429. 
and modern sources, the purpose of this writing is to advance a reflection on ancient Attic democracy, in order to point out three foundations of this form of government: political autonomy, participation, and "control."

\section{Keywords:}

Athens, autonomy, city, control, participation, political system, Aristotle.

Han transcurrido más de 120 años desde que un aislado vertedero de basuras, situado en Oxirrinco, en la actual El Bahnasa, a unos 150 kilómetros de El Cairo, dejara al descubierto cientos de papiros antiguos. Entre los documentos encontrados, uno habría de llamar pronto la atención de los estudiosos debido a su buen estado de conservación: el tratado, casi íntegro, de la Constitución de los atenienses (en adelante Ath.), ${ }_{1}^{1}$ también traducido como Régimen político de los atenienses, y preparado y redactado por Aristóteles hacia el final de sus días, al parecer, con vistas a una eventual publicación (Tovar, 2000). Sin contar los "fragmentos del comienzo tardío" (ocho textos cortos en los que diversos autores griegos -Heráclides, Harpocración, Estrabón, Plutarco y otros escoliastas anónimoscomentan el tratado aristotélico), el texto, tal como hoy se conserva, consta, en total, de 69 secciones. Estas se pueden agrupar en dos grandes conjuntos.

En el primero, que va desde el inicio hasta la sección 41, Aristóteles reconstruye históricamente once cambios constitucionales acaecidos en Atenas entre los siglos VII y IV a. C. El catálogo de los regímenes es amplio y heterogéneo: se extiende desde las monarquías heroicas anteriores a Teseo, pasando por la timocracia de Solón, la cruel tiranía de Hipias, el sistema republicano de Clístenes, la añeja aristocracia del Areópago y las oligarquías radicales de los Cuatrocientos y los Treinta (Ath. 32, 2 ss.; 34, 2-3), hasta culminar en la democracia extrema que le toca vivir a Aristóteles, cuando un fervor antimacedónico lo obliga a trasladarse a la ciudad de Calcis, donde habrá de morir en el año 322 a. C.

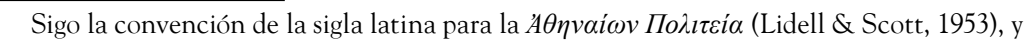
lo mismo para las demás abreviaturas de las obras clásicas propuestas en dicho Lexicon. 
Y en el segundo, comprendido entre las secciones 42 y 69, el Estagirita, recurriendo a fuentes dispares (atidógrafos locales, tratados doctrinales, archivos oficiales y fuentes similares), da a conocer, con detallada morosidad y espíritu de archivista, el modo como operan las diversas magistraturas, los quehaceres desempeñados por un sinnúmero de funcionarios, los tipos de elección de los cargos, la dinámica de las asambleas, la organización de los tribunales y demás cuestiones relativas a la democracia, entendida como el régimen político en el que el dêmos ("la comunidad de los ciudadanos"), actuando como depositario último de la soberanía, se hace cargo de la conducción de la ciudad (Ath. 6, 2; 18, 4; 44, 4, ss.; Berti, 2012, p. 77).

Reparando en algunos pasajes de las dos partes mencionadas, y ahondando en el contenido de otras fuentes antiguas y modernas, este artículo pretende ofrecer unas cuantas reflexiones históricofilosóficas sobre la antigua democracia ateniense; en concreto, sobre la democracia que, salvo los períodos oligárquicos del 411 y el 404 a. C. en los que el régimen se interrumpe a causa de la alianza de los espartanos con los persas y la capitulación de Atenas (Ath. 29, 1), habría de mostrar, en este primer florecimiento, una vigencia de más de ciento cincuenta años.

Nuestro cometido es inseparable de una empresa compartida por decenas de estudiosos que, afincándose en una tradición de pensamiento impregnada de ímpetu investigativo, procura no tanto rehacer el acontecer democrático ateniense en sí mismo (cosa de suyo imposible), sino construir o reconstruir un sentido de este; sentido, por definición, irreductible a una elaboración definitiva.

Procederemos, en consecuencia, no reseñando solo fechas, nombres de personajes, datos, acontecimientos, prácticas sociales e instituciones, ni tampoco formulando o exponiendo únicamente categorías de pensamiento, modos de razonar, creencias religiosas, valores morales y otras representaciones mentales, sino promoviendo un diálogo entre realidades de hecho inherentes al tema elegido y ciertas nociones teóricas que resuenan con fuerza en aquellas. Conjeturamos que tres palabras, dotadas de hondo calado histórico y una explícita vocación conceptual, habrán de servirnos para delimitar los alcances de este escrito, a saber: (a) autonomía, (b) 
participación y (c) "control". Esperamos poder ilustrar cómo ellas palpitan implícita o explícitamente en el tejido discursivo del tratado aristotélico, y cómo, asimismo, las relaciones que mantienen entre sí, y con otras fuentes, confieren significación a aquella forma de gobierno en la que el pueblo pregona -con un ánimo exultante-que se hace dueño de un destino conjunto.

Entremos en materia.

\section{Autonomía}

Surgida aproximadamente tres siglos antes de que los atenienses consoliden el régimen democrático, una serie de transformaciones culturales ocurridas a comienzos del siglo viI a. C. reemplaza a las estructuras palatinas de los antiguos reinos minoicos y micénicos (Barahona, 2008; Bianchi, 1981; González, 2004; Hall, 2020; Martínez, 2015). Desde entonces la ciudad se erige, en términos físicos, como asentamiento humano, no muy extenso, que comprende un núcleo urbano integrado por casas familiares, edificios públicos, templos y santuarios comunes, vías principales y secundarias, así como tierras de labranza y pastoreo necesarias para garantizar la coexistencia, la convivencia y la independencia económica (Berti, 2012; Cruz Vélez, 2015; Hansen y Nielsen, 2004); y, en términos espirituales, o, si se quiere, filosóficos, como morada común, ontológicamente anterior a la casa familiar y la aldea, en tanto unidades de organización naturales, donde los hombres, tras alcanzar su pleno desarrollo, pueden desplegar todas sus potencialidades individuales y actualizar el fin que le confiere pleno valor al acto de creación de aquella: una vida marcada menos por el placer que por el bien o, mejor, por la felicidad (Arist. Pol. III, 1278b6, 3-4).

En muchas metrópolis, y en no pocas colonias, la antigua ciudadela real que se alza sobre las planicies de los centros de poder, y en torno de la cual transcurre la vida cotidiana de quienes producen los bienes necesarios para satisfacer los requerimientos de los hombres que detentan el poder, cede su lugar a un espacio colectivo que, con el correr de los años, pasa a ser considerado como el corazón de la vida social y política, o, según la imagen poética de Píndaro, 
como "el ómphalos (el ombligo) de la ciudad" (fr. 75). Hablamos del ágora, esa prenda de distinción de toda polis griega y que, según el relato de Heródoto, no suscita en Ciro el Grande más que un juicio peyorativo al considerar que "es el lugar a propósito para reunirse y engañarse unos a otros [los hombres] con sus juramentos" (Hdt. Hist. I, 153). A despecho del suspicaz dictamen de Ciro, el ágora es, ante todo, un espacio de convergencia, acondicionado expresamente para facilitar el intercambio de opiniones, rumores y pensamientos, y la compraventa de productos, mercancías y servicios.

Como núcleo urbano, el ágora, concretamente en Atenas, llega a ser a la vez un espacio religioso y político. Religioso, puesto que una suerte de sanción sagrada lo protege. No en vano, la misma deidad que preserva la casa familiar, la Hestia doméstica, expresión cultual de las funciones que denotan el arraigo hogareño y la comunicación con el cielo a través de las plegarias y los sacrificios domésticos, será instalada en el ágora, con el nombre de Hestia koiné, una divinidad femenina, inviolable y poderosa. Dicha proclama implica que el ágora es considerada por los atenienses como "hogar común" y, por ende, que no puede ser intervenido arquitectónicamente por nadie y menos profanado con actos sacrílegos, impíos o injustos. Llega a ser también político, puesto que constituye la manifestación simbólica del acto por medio del cual los atenienses, en su condición de cultores y amantes de la palabra, de filólogos (Th. Hist. II , 40, 2-3), asocian la administración y gestión de los asuntos comunes con la existencia de un espacio común, ácrata, "no apropiable, público, abierto a los ojos de todos, socialmente controlado, donde la opinión de cualquiera, libremente expresada mediante la palabra en el curso de un debate general, es puesta a disposición de la mancomunidad" (Vernant, 2008, p. 135). Diríase, entonces, que el ágora ateniense, afirmado en la consagración de una deidad en cuyo culto se trasluce el vínculo del interior doméstico con el exterior público, representa el modelo espacial de una concepción urbanística en la que el poder se deposita en el centro (Ath. 38, 1; Vernant, 2008, p. 143).

Depositar, por así decirlo, el poder en el centro (en el ágora), en medio de quienes conforman la ciudad, implica organizar el espacio en un haz de relaciones humanas "simétricas y reversibles", 
que no asimétricas y hegemónicas (Ezquerra, 2009, p. 23). El fin de esta reorganización no es otro que suscitar entre los miembros de la colectividad el sentimiento de que cada uno "puede mandar y obedecer, a sí mismo y al mismo tiempo a los demás, y así afirmarse libres de toda dominación" (Vernant, 1973, p. 198). Dicho gesto de afirmación supone, igualmente, la toma de conciencia de que, más allá de la vida familiar, donde el señor de la casa ejerce una autoridad despótica sobre los esclavos, una autoridad política sobre la esposa y una autoridad señorial sobre los hijos (Arist. Pol. I, 1253b1-14), existe la opción de desarrollar una segunda clase de vida, la vida política, cimentada más en "la libertad que en la necesidad" (Arendt, 2006 [1958], p. 34; Jaeger, 2008 [1934], p. 114); libertad asumida no solo como "derecho al movimiento no restringido", sino, sobre todo, como proceso de autoafirmación social, vale acotar, como conjunto de fases sucesivas destinadas a la consecución de un fin unitario: la construcción de una vida en común. A este respecto, ya sugería Arendt (2006) que, en teoría, un ciudadano podía consagrar libremente sus días a la demandante actividad política de la Atenas democrática solo a condición de que resolviera con anterioridad los problemas concernientes a la alimentación, el vestuario y la vivienda de cada uno de los integrantes del grupo familiar (2006, pp. 42-43). Quizás sea la convergencia de estos dos elementos (a saber, concebir una noción de poder al alcance de la mayoría y hacer un uso de la libertad que tome en cuenta los asuntos comunes) la que contribuya a explicar el señalamiento de Tucídides según el cual "la polis son los hombres, pues son éstos quienes hacen una ciudad, y no las murallas y las naves vacías de tropas" (Hist. VII, 77).

La conciencia del refinamiento político que se desprende del hecho de poner el poder en el centro, es decir, de "arrancarlo del secreto para convertirlo en un objeto de pensamiento y debate público" con miras a establecer el vínculo que existe entre poder y ley (Vernant, 2008, p. 145), no se produce a golpes del azar ni tampoco sin que la ciudad se vea sacudida por un movimiento intelectual, de profundas repercusiones sociales, desarrollado a mediados del siglo $\mathrm{v}$ a. C. y fomentado por un grupo de personajes ambulantes que se denominan a sí mismos "maestros de sabiduría": 
el movimiento sofístico. Con una actitud de indómita arrogancia y amparados en el conocimiento que han adquirido por el hecho de ser ciudadanos de todas partes y de ninguna, los sofistas, aparte de cobrar por las enseñanzas que imparten -areté-, exhiben un irrestricto escepticismo respecto de las más variadas cuestiones humanas: la naturaleza de los dioses, los sentimientos morales, la comunicación del saber, las percepciones sensoriales, la comprensión física del cosmos, entre otras (Guthrie, 1995 [1958], pp. 78-79). Propensos a trastocar certidumbres, costumbres y valores, y abastecidos de recursos retóricos destinados a suscitar aporías, ambigüedades semánticas y discursos contradictorios, estos educadores peregrinos no olvidan hacer de las leyes un recurrente blanco de ataque. Jugando con las vacilaciones del vocabulario legal que campea en Atenas, pues la ciudad todavía no cuenta "con una noción de ley absoluta y mucho menos de una reglamentación constitucional basada en principios y organizada a modo de sistema coherente" (Critchley, 2020, p. 69), y poniendo en el primer plano de la discusión pública la oposición entre physis y nomos (naturaleza y convención), una oposición por lo demás en la que late la antinomia filosófica entre ser y parecer (Guthrie, 2003 [1962], p. 66), los sofistas transfieren al dominio del derecho y de la moral el alcance de sus reflexiones.

Dos posturas discrepantes, a este último respecto, son acogidas en algunos círculos sociales de la ciudad, siempre ávida de abrirse a los "visitantes y a las opiniones que éstos traen consigo" (Hall, 2020, p. 179). La que, deteniéndose en la observación del modo como la naturaleza impone un orden regular a todas las cosas, concibe e interpreta las leyes en términos de creación coactiva cuyo fundamento es la fuerza, la dominación o la violencia físicas; y la que, sin desoír el llamado de la necesidad, suscribe la convicción de que las leyes, así como también "lo honesto y lo deshonesto, lo justo y lo injusto, lo piadoso y lo impío, y cuanto cada ciudad determine” (Pl. Tht., 172a), son el resultado de un convenio cuyo estricto acatamiento es garantía de seguridad individual y estabilidad social (Pl. Crit., 52b-c).

Recalando en la primera postura, algunos sofistas extreman su recelo respecto de la naturaleza de las leyes. Estas, a juicio de Antifonte, no son más que una mordaza que se usa para restringir "el ejercicio de 
los sentidos" (De Romilly, 2004, p. 61); o, conforme al dictamen de Hipias, constituyen una forma velada de tiranía (Pl. Prt., 337d); o, en palabras de Trasímaco, y aún del mismo Gorgias, son instrumentos eficaces para doblegar la voluntad de los más débiles (Pl. R. I, 338c-d; Grg., 483-484a). Suscribiendo la segunda, otros, como Protágoras, ponderan la necesidad y utilidad de las leyes, dada la aviesa tendencia de los hombres a transgredir cualquier clase de freno que restrinja sus deseos o ambiciones (Rodríguez Adrados, 1998, pp. 183-186). En un sentido similar, Sócrates las define como decisiones conjuntas al cabo de las cuales los hombres, sin ser forzados a ello, decretan "lo que se debe hacer y lo que no" (X. Rec. 1, 2, 42) y lo que, en definitiva, puede asegurar la salud de la ciudad.

Con la invención de la tragedia, valorada no solo como forma de arte cimentada en el modo de la imitación poética, sino también como institución social patrocinada por ciudadanos acaudalados, la ciudad tercia en la discordia que opone a ambas posturas y opta por la segunda. En el Prometeo, de Esquilo, el Titán invoca las "nuevas leyes", en contra del "poder sin regla" ejercido por el joven Zeus (vv. 149-151); Sófocles, a su vez, en el Edipo en Colono, hace decir a Teseo que Atenas es la polis en la que nada se realiza que "esté fuera de la ley" (v. 915); y, por último, Eurípides, en Medea, nos hace testigos de los argumentos desarrollados por Jasón para hacerle comprender a la heroína que nada le debe: "Es innegable, no obstante, que por mi salvación, has recibido más de lo que has entregado. Me explicaré: en primer lugar, habitas tierra griega y no extranjera, y conoces la justicia y sabes utilizar las leyes sin dar gusto a la fuerza" (vv. 536-539).

Y al optar por la segunda postura, es decir, por la ley escrita forjada en términos de convención, la ciudad, pese al descontento de la facción oligárquica encarnada por los miembros que integran el Consejo del Areópago (Ath. 3, 6) y a la animadversión de los particulares que sacan partido de las "profesiones de fe amorales" difundidas por algunos sofistas (De Romilly, 2004, p. 83), traza un camino común avivado por dos deseos: prohibir que en Atenas se vuelva a implantar un gobierno unipersonal cimentado en la ley del más fuerte, o, lo que es igual, frenar el rebrote de la tiranía como 
forma de gobierno auspiciada por una minoría rica y de costumbres reaccionarias (Ath. 16, 10; Arist. Pol. Iv, 1295b11, 4-6, Rh. II, 1390b16, $35 \mathrm{Pl}$. Lg. v, 742e), y acordar una noción de ley entendida como pacto social cuya observancia incondicional, más allá de cualquier caso particular, llega a ser prenda de garantía de una justicia cívica.

Traducidas en proposiciones o juicios que entrañan el discernimiento de lo que es útil (porque no perjudica), piadoso (porque respeta los asuntos que atañen a los dioses) y conveniente (porque procura dar lo debido a cada cual y a la comunidad misma), las leyes se erigen como normas racionales supraindividuales con base en las cuales la ciudad de Atenas intenta modelar, hasta donde ello es posible, la composición de su propia estructura jurídicoconstitucional. Si las murallas de la ciudad constituyen un lugar sagrado cuyas lindes marcan la frontera entre el interior y el exterior, las leyes son la creación colectiva que le otorga cohesión al "cuerpo político" (Arendt, 2006, p. 71). De ahí que, para los atenienses, sea más razonable establecer las leyes de una ciudad conforme al régimen existente (o que se desea instaurar), y no la forma de gobierno, teniendo a la mano, para ello, "leyes" previas (Arist. Pol. IV, 1289a 9-10 Isóc. Pan., 14-15). Elegir crear leyes democráticas implica preferir lo colectivo a lo individual, lo deliberativo a lo impositivo, lo escrito a lo oral, lo seguro a lo volátil y lo racional a lo pasional. Tal elección no hace otra cosa que materializar el precepto de Heráclito según el cual el pueblo ha de luchar tanto por sus murallas como por sus leyes (D.L. IX, 2).

Pero esto implica una audaz mudanza política. En efecto, por vez primera, y en contra de una larga tradición que jamás ha sido objeto de cuestionamiento, los atenienses, sorteando discrepancias de intereses y disputas sobre privilegios de "clase", aceptan que el poder ya no es patrimonio exclusivo de un "pastor de huestes" (fórmula que, con pequeñas variaciones, se repite una y otra vez en Homero -cfr. Il. II, 254; v, 38; VI, 99, etc.; Od. III, 157, 470; IV, 24, 532; XXIV, 121), ni tampoco de un grupo de individuos que se consideran a sí mismos como los únicos depositarios de las virtudes del honor, la astucia y el valor $-y$, por lo tanto, los llamados a granjearse para sí una "fama imperecedera" (Detienne, 2004 [1967], pp. 67-68)-, sino, por 
insólito que parezca, de la colectividad en general. Un hecho viene a reforzar este cambio de concepción de la soberanía: a contrapelo de otras ciudades griegas como Esparta o Gortina, que se precian de contar con constituciones inspiradas por voces divinas, Atenas toma conciencia de que no goza de una fuente extrasocial, de índole religiosa, que dicte las leyes con las cuales se estructura el orden de la ciudad, o que establezca la naturaleza, estructura y funcionamiento de los cargos de gobierno.

Al no contar, pues, con una base sustantiva que actúe como fundamento (heteronómico) "del carácter justo o injusto, apropiado o inapropiado de una ley en particular o de determinado estado de cosas" (Castoriadis, 2005, p. 115), son los mismos atenienses quienes, asentados en las gradas de la Pnyx, en asamblea popular, toman la decisión, libre, independiente y soberana, de proponer, discutir y aprobar, con el auxilio del logos, y manteniendo a raya toda manifestación de violencia o fuerza bruta, las leyes (del matrimonio, de la crianza de los hijos, de los sacrificios y ritos cultuales, de la manutención de las viudas y huérfanas, del manejo económico de los tributos de los aliados, etcétera) bajo cuyo alcance se comprometen a encauzar sus acciones individuales y colectivas, a fin de evitar, según expresa el dístico de Solón, "que la tierra más vieja de Jonia sea asesinada" (Ath. 5, 2), ya por discordias internas entre ricos y pobres (Rodríguez Adrados, 2011, pp. 48-49), ya por el deseo de alguno de hacerse con el mando y la autoridad, o, planteado de otro modo, con el objetivo de entregar, conforme al amplio designio de Clístenes (Ath. 22, 1), el régimen al pueblo, al dêmos.

Organizado y distribuido en funciones de gobierno, es el pueblo quien establece las leyes, dicta sentencia y fija las penas y castigos en casos de trasgresión. Es a ese sujeto colectivo, actuando por sí mismo y conteniendo la eventual coerción ejercida por una fuerza sobrenatural o natural, al que le compete declarar que Atenas se autogobierna y asume los riesgos y las consecuencias de semejante declaración. Por ende, la autonomía convierte a la ley en el substituto de la violencia o fuerza de dominación, privándola de toda legitimidad. Como quiera que no hay ley que no presuponga una idea compartida de justicia (diké), ni una concepción de justicia que no se plasme en el texto de 
una ley, entonces la diada ley-justicia (nómos-diké) se transforma en el horizonte político supremo hacia el cual se orienta en la Atenas democrática toda acción colectiva.

La colectividad, como agente responsable de la creación y sostenimiento del régimen democrático y, por ende, que se interroga arduamente acerca de las causas, los instrumentos, los fines, los modos y los límites de las acciones humanas (fundamento de toda decisión que puede recibir una sanción legal), "no es absolutamente idéntica a la suma de los ciudadanos presentes en un día cualquiera en la ekklesía y tampoco a los atenienses vivos en un momento dado" (Castoriadis, 2012, p. 120); pero estos, al mismo tiempo, parecen tener claro que, sin perjuicio de la actuación regular de la Asamblea o del funcionamiento ordinario del Consejo, la polis solo pude perdurar a condición de que se la sitúe por encima de cualquier "órgano de gobierno" (Hansen, 2009 [1991], p. 195).

Por eso cuando el dêmos, reunido en los espacios correspondientes para dar trámite a los temas que son objeto de deliberación (aprovisionamiento de cereales; estrategias para defender la seguridad de la ciudad; pertinencia de las acusaciones de alta traición o conspiración; examen de las denuncias de los sicofantes; conveniencia de las suplicaciones privadas o públicas, etcétera; Ath. 43, 4-6), completa la agenda propuesta para el día, y pasa a la fase de votación, clausura el encuentro con una frase que condensa el sentir de la voluntad general y que sirve, al mismo tiempo, para mostrar la senda de comportamiento que han de seguir los ciudadanos: "Así se establece o determina por el Consejo y por el Pueblo". Por el Consejo, integrado por quinientos ciudadanos, a razón de cincuenta por cada tribu, y todos elegidos por sorteo, porque la ciudad, acatando una prescripción emitida un siglo antes por Solón, no somete a consideración de la Asamblea nada que previamente no haya sido examinado por él mismo (Ath. 44, 2-3). Y por el Pueblo, ya que es este el que fija para la ciudad o, lo que es igual, para los ciudadanos mismos, las leyes (nómoi) y decretos (psephismata) que regulan las conductas individuales y colectivas. En consecuencia, antes que ser una mera fórmula de cortesía política, grabada por lo demás en multitud de estelas de piedra como recordatorio de la afirmación de una identidad y cohesión colectivas, la frase testimonia 
el carácter inalienable, soberano y vinculante de un pueblo que, al hacerse dueño del voto, impelido por el vigor de la autonomía, "se hace dueño del gobierno" (Ath. 9, 1-2).

Tras ser proclamada la ley, a viva voz y a plena luz del día (un hecho no carente de significación, dado que es la expresión de la transparencia -y no del secreto- con que ha de comportarse la voluntad general), la mancomunidad reconoce, tras una apasionada jornada de "debate, análisis intelectual, experiencia razonada y reflexión positiva" (Vernant, 2008, p. 145), que el único poder aceptable, el único que es objeto de temor y respeto y el único al cual en adelante resulta sensato obedecer, por estar colmado de un valor justo y supremo, es el que emana del nómos común.

De ahí que la labor de los seis arcontes "legisladores" (thesmothétai) sea, no la de referir las presuntas normas divinas propias del derecho consuetudinario, sino la de "trasladar a escrito las leyes" que son producto de los acuerdos humanos y fruto del voto del cuerpo cívico congregado en Asamblea (Ath. 3, 4). Como magistrados que encarnan el poder ejecutivo, los tesmótetas regulan una parte vital de la vida cotidiana ateniense: la que atañe a la compleja administración de justicia de la polis (Ath. 59, 1). Teniendo como marco el conjunto normativo fijado por escrito, dicho grupo de ciudadanos estudia las leyes, las revisa, las interpreta (en especial aquellas cuya aplicación procede de las causas presentadas, sean privadas -díkai-, sean públicas -graphaí-) y, si es del caso, por haber encontrado algún tipo de vacío legislativo o alguna clase de imperfección jurídica, se arroga el derecho de proponer correcciones o, incluso, nuevas leyes. La relación emitida por los tesmótetas pasa a la Asamblea, que entonces procede a deliberar sobre la conveniencia o inconveniencia de tal informe. De ser validado, dicho órgano, a su vez, autoriza la conformación de un cuerpo especial (el colegio de los nomothétai), elegido de entre los integrantes de los tribunales (Ath. 3, 5), a fin de que se pronuncie sobre el particular. El último bucle de esta espiral constituyente corre a cargo de la Asamblea que, de aprobar el pronunciamiento, enuncia la última palabra.

Lo que sigue, y cierra el proceso, es un acto de didáctica publicidad, otrora promovido por Solón (Ath. 7, 1): las leyes se exponen en 
lugares públicos, como si de carteles se tratara, de suerte que sean visibles y legibles por los habitantes de la ciudad, para hacer saber a todos, propios y extraños, las disposiciones aprobadas por el pleno de los ciudadanos concentrados en la roca sagrada de la Pnyx. Una vez divulgadas, las leyes tienen la pretensión de asegurar la conformación de una cultura común, necesaria para impulsar la participación política, militar y cultural en los asuntos de la comunidad.

\section{Participación}

A pesar de las escasas líneas que le dedica a Clístenes, Aristóteles lo ubica entre los forjadores del régimen democrático. Por ello, previo a la exposición de los frentes de acción de este "jefe de pueblo" (Ath. 20 , 4), desentraña la intención de la reforma puesta en marcha por aquel en el año 508/7 a. C.: dividir el territorio del Ática, antes segmentado en cuatro tribus (phylai) o asociaciones gentilicias y religiosas, en nuevas unidades geográfico-administrativas (diez, en total), para que, una vez mezclada la población, y disueltas las antiguas alianzas familiares y las viejas jerarquías regionales, pueda participar un "mayor número en el gobierno" (Ath. 21, 2-3). Esta última afirmación, puntual y escueta, pero no menos relevante, en cierta medida hace eco a las palabras puestas por Tucídides en boca de Pericles: "tenemos un régimen político que no emula las leyes de otros pueblos y, más que imitadores de los demás, somos un modelo para seguir. Su nombre, debido a que el gobierno no depende de unos pocos sino de la mayoría, es democracia" (Hist. II, 37, 1). Sin necesidad de levantar un complejo y "articulado edificio institucional" (García Moreno, 2008, p. 75), Clístenes concederá a muchos, diríase a cientos o, mejor, a miles de individuos, algo que jamás habían soñado tener: igualdad en el reparto de derechos y deberes (Hdt. Hist. III, 80 y 142). Dicha igualdad ante la ley (isonomía) es el nuevo basamento de un ordenamiento legal y político en el que los votos deciden la fortuna o el infortunio de todos. Atentar contra el mecanismo de la votación se traduce en "la revolución, la ruptura y el desastre" (Rodríguez Adrados, 2008, p. 38). 
Participar, y no permanecer impasible o neutral ante realidades presentes y futuras -que pueden afectar, a veces fatalmente, el bienestar general del cuerpo cívico- es la potencia de acción que subyace a la maniobra constitucional de Clístenes. Restringiendo la pregunta solo al factor político (y no a otras causas que incidirían negativamente en la plasmación de dicha potencia, como la falta de tiempo libre, la carencia de una educación retórica, la precariedad de recursos materiales, por no hablar de las dificultades de desplazamiento para acercarse a la ciudad y permanecer en ella el tiempo que sea necesario a fin de ejercer un cargo público, dada la "diversidad física de las distintas zonas del Ática” [Sinclair, 1999, pp. 327-335]), ¿quién está facultado para participar? Cualquier hombre que, habiendo sido enlistado en la nómina demótica tras cumplir la edad de 18 años (Ath. 21, 4-6; 55, 3), satisfaga un requisito esencial: acreditar la condición de ciudadano. Lo cual significa que, a resultas de las reformas de Clístenes, la participación y la ciudadanía, esa otra invención de los atenienses (Olalla, 2015, p. 20), van aparejadas. En efecto, si antes la ciudadanía se obtiene por la vía de la filiación genealógica (en principio, ser hijo de padre ateniense y, luego, en el 451 a. C., merced a una ley fijada por Pericles, ser hijo de padre y madre atenienses; Ath. 26, 4), después se configura, no por residir en Atenas (pues las mujeres, los extranjeros y los esclavos están excluidos de ella aun viviendo en el mismo lugar), ni tampoco por contar con el derecho de incoar procesos judiciales o de ser sometidos a ellos, sino por participar, y por ningún otro rasgo, "en las funciones judiciales y de gobierno" (Arist. Pol. III, 1275a3-5). Y se es tanto más ciudadano de plenos derechos políticos cuanto menos se ponga en duda el lazo sanguíneo con antepasados atenienses y la disposición de servir públicamente a la comunidad.

Nótese que decimos participación, en el doble sentido de "ser parte de" y de "tomar parte en", y no representación. Participación general igualitaria, a pesar de que muchos antepongan las preocupaciones individuales y familiares a las de la comunidad y terminen desentendiéndose de los afanes de la vida pública (Sinclair, 1999, p. 328), puesto que la ciudad otorga al dêmos la posibilidad de poner en práctica tres derechos políticos: isegoría (hacer proposiciones ante 
el pleno de la Asamblea), isopsephia (las voces de quienes hablan en público "se valoran por igual") y parresía (hacer uso libre de la palabra, a condición de que hablen con absoluta sinceridad y, más relevante aun, con verdad, así esta se revele impopular o contraria a un consenso [Foucault, 2004, pp. 35-52; García Moreno, 2008, p. 87]). La concreción de estos tres derechos, bajo modalidades discursivas que responden a códigos diferentes según sea la función y el espacio institucional donde se hacen efectivos (Arist. Rh. I, 1358b $\mathrm{b}_{2-7}$ ), remodela el espacio cívico transformando la forma de gobierno en una democracia directa o radical, en la que el voto, como manifestación decisiva de un acto de deliberación, juzgamiento o administración, se convierte en signo vinculante de la participación política.

En otros términos, si un ciudadano revela lo que es, lo que piensa y lo que desea por medio de su voto, y si este entraña la expresión de su voluntad en orden a reflejar una preferencia, entonces el ciudadano que vota, bien a mano alzada, bien en urna secreta, se constituye, por así decirlo, en el centro de gravedad de la iniciativa y autoridad políticas. Por tal razón, nadie que no sea el ciudadano mismo se puede arrogar para sí el papel de la representación y obrar en nombre de un grupo local, una facción de partido o un caudillo encubierto (Castoriadis, 2012, pp. 110-111). La consecuencia es clara: el sistema de gobierno activado por Clístenes, y perfeccionado después por Efialtes, en el año 462 a. C., cuando decide despojar a los exarcontes que integran el Consejo del Areópago de sus viejos e intocados privilegios (Ath. 25, 1; Esquilo, Eu., 681-706), es una democracia directa, radical, no indirecta o representativa.

Y directa, no representativa, en tres sentidos: (a) el depositario del poder político deja de ser un agente humano individual, una casta de sacerdotes refugiada en el hermetismo de un lenguaje pletórico de fórmulas mistagógicas y ensalmos sobrecogedores -o una minoría de ricos y libres que gustan de "reivindicar a un héroe por ancestro" (Castoriadis, 2012, p. 87), y ahora es encarnado por un sujeto colectivo: el dêmos; (b) este dêmos, antes que obrar políticamente en nombre de intereses de facción, clase o partido, se exterioriza como cuerpo cívico y, más, como unidad-múltiple en la que no se excluye la actuación individual, y da a conocer, mediante el voto destinado 
al conteo, el dictamen de su decisión; y (c) al no representar a nadie, el poder de la colectividad, actuando de consejero, operando como juez o deliberando como miembro de la Asamblea, se convierte en causa, signo y efecto de su propio y autónomo destino político. En definitiva, la idea "de que el poder soberano, si bien está en posesión del pueblo, no puede ser ejercido por este como tal, y debe pasar por la mediación de sus representantes, se desconoce por completo" (Castoriadis, 2012, p. 104). Lo cual no supone que la ciudad se ciegue a la posibilidad y necesidad de nombrar emisarios o comisionados (Ath. 37, 2), o que impida que un orador, como partidario del pueblo (Ath. 6, 2; 16, 9; 18, 5), tome la vocería de un sector de la sociedad, y hable ante el cuerpo cívico.

Es, pues, el ciudadano, en su calidad de votante, y no un delegado o un representante, quien autentica -con habas blancas y de colores, ramos de olivo, dados de bronce $\mathrm{u}$ otros utensilios de sorteo (Ath. 8, 1 y 22,$5 ; 43,5$ y 63,2 ), objetos dotados de un valor no menos funcional que simbólico- el contenido de su decisión, en asuntos que conciernen a los magistrados, las actividades de los consejeros y las penas y castigos judiciales. De ese modo, la ciudad se asegura de que el poder de decisión no sea transferido a agentes políticos indirectos y permanezca solo en manos de aquellos que han optado por gobernarse a sí mismos, en el marco de una forma de gobierno en el que la sostenibilidad económica es solidaria de la autonomía política.

Unido a este aspecto, en virtud del cual la democracia ateniense evita que la participación se reduzca al acto de "decidir quién va a decidir", rasgo característico de una constitución afincada en el principio de la representatividad (Castoriadis, 2012, p. 129), conviene apuntar que la participación en los asuntos de gobierno deriva de una férrea convicción colectiva según la cual no existe, en materia política, como sí ocurre en otros dominios de la acción productiva (por ejemplo, la construcción de navíos mercantes o de transporte, el diseño y edificación de templos y santuarios religiosos, la fabricación de pertrechos bélicos, etcétera) un saber técnico especializado que sirva de fundamento a la actividad misma. Dicha convicción, expuesta dialógicamente por Protágoras en el texto homónimo de Platón, establece que, en el caso hipotético de que tal saber existiera, 
y fuera invocado en el momento de conceder a alguien la autorización para desempeñar un cargo público, pertenecería por igual a todos, habida cuenta de que es el producto de una dación divina (de Zeus, en concreto), pero en ninguna circunstancia sería un conocimiento exclusivo de unos cuantos individuos (Pl. Prt., 322d y ss.). Para los atenienses, dicho en breve, no tiene sentido hablar, ni desde una perspectiva teórica ni desde una práctica, de especialistas políticos.

Dotado de derechos políticos, los ciudadanos han de devolver a la ciudad, a título de deberes, lo que de ella reciben. Sin ahondar en deberes morales como respetar a los padres y velar por su cuidado durante la vejez, encargarse de la crianza y educación de los hijos o prestar asistencia a las viudas y huérfanas (Ath. 56, 6-7), ni en deberes cívicos como el de obrar en calidad de juez arbitral una vez cumplidos los sesenta años (Ath. 53, 4-5), y menos en el deber religioso de unirse a la procesión de las Panateneas con la cual Atenas celebra el nacimiento de su diosa tutelar (Ath. 18, 2-3), la ciudad concede a los deberes militares una enorme relevancia. No existiendo en propiedad un cuerpo de policía ni un ejército profesional que garantice la seguridad interna y la defensa externa de Atenas (pues los mil doscientos esclavos escitas de propiedad de la ciudad actúan como guardia que controla "el orden en la Asamblea, en los Tribunales y en otros foros públicos", cuando no es que operan como custodia "de diversos magistrados" [Sinclair, 1999, p. 336]), son los mismos ciudadanos quienes se encargan de la protección de la comunidad. De dos maneras diferentes puede efectuarse dicha protección: financiando parte del aparato militar o encarnando la función del ciudadano-guerrero (Hanson, 2006, pp. 57-62).

En el primer caso, se expresa la adhesión al propósito común de salvaguardar la vida de todos los habitantes del Ática aceptando pagar una especie de impuesto de guerra o tributo, destinado a costear la construcción y dotación requeridas por un trirreme o cuadrirreme, en cuanto máquina necesaria para llevar a cabo el combate naval (Ath. 22, 7; 46, 1). Los contribuyentes de estas liturgias, en su mayoría ricos, reciben el nombre de trierarcas y, por ley, se les otorga la posibilidad de ser exonerados de la imposición del tributo si logran demostrar ante los estrategos que se encuentran 
económicamente sobrecargados o, en su lugar, se les invita a unirse a otro conciudadano para compartir los gastos (Ath. 56, 3). En el segundo caso, el ciudadano, conforme a la "clase censataria" a la cual pertenece, puede incorporarse a una unidad de caballería al mando de un oficial competente y experimentado (Ath. 49, 1; X. Oec., IX, 15) o a un destacamento de infantería pesada (falange de hoplitas) o ligera (arqueros u honderos) (Ath. 24, 3; 42, 3).

La unidad del cuerpo político, que se manifiesta en el espacio público institucional (donde sesionan los areopagitas, los ciudadanos que año tras año integran el Consejo de los Quinientos, los jueces que componen los Tribunales, los hombres que desempeñan las Magistraturas mayores y menores, y donde además el dêmos delibera en Asamblea), es la consecuencia de las palabras y acciones generadas por los ejecutantes de estas y los que las "padecen o reciben" (Ezquerra, 2009, p. 22). Visible en la adopción de la falange hoplítica, en cuanto técnica militar puesta en práctica para reproducir emblemáticamente la solidaridad del grupo que tiene el deber de enfrentarse a los peligros externos a fin de rechazarlos o eliminarlos y, de esa manera, garantizar la seguridad de todos los habitantes de la polis (ciudadanos y no ciudadanos), esa unidad no puede ser alcanzada a menos que la participación, ahora liberada de la sombra de cualquier forma de esclavitud (Lane, 2007, p. 132), se apuntale en ciertos procedimientos formales capaces de proveer a la democracia un nuevo ethos político.

Prolongando y retocando elementos pertenecientes a su propia tradición, los atenienses acuerdan un par de procedimientos: uno, relativo a la duración de los cargos y, otro, a los mecanismos empleados para hacer efectiva la asignación.

Respecto del primero, la norma es taxativa: salvo la función vitalicia de los areopagitas, todas las demás dignidades públicas se limitan a un año, y solo a uno. Con tal especificación temporal, se busca, por una parte, que un ciudadano intervenga en diferentes emplazamientos de gobierno, de suerte que pueda alcanzar una comprensión más integral del funcionamiento de la ciudad; y, por otra, se intenta evitar que el poder, avivado por la semilla que hace brotar "la energía del querer" (Arist. Pol. III, 1287a ${ }_{5-6}$ ), se adueñe del corazón 
de los hombres, tornándolos esclavos de sus propias ambiciones y, al extremo, acabe trayendo la ruina a toda la comunidad.

En lo que atañe al segundo procedimiento, la asignación comporta dos arreglos: el sorteo y la elección.

Como impronta distintiva de la democracia griega (García Moreno, 2008, p. 97; Lane, 2007, p. 138; Mosse, 1987, p. 29), el sorteo corrobora la concepción ateniense de que, respecto de los asuntos comunes, resulta improcedente alegar la posesión individual de una experticia política, sobre todo cuando se trata de distribuir, entre miles de ciudadanos que se saben amparados por el derecho de la isopoliteia, un abultado número de magistraturas que son indispensables para la buena marcha de la ciudad (Ath. 47-54). Ni siquiera los criterios de la opulencia, la estirpe o la educación recibida mueven a los atenienses a desembarazarse del azar como dispositivo de asignación de los cargos. Otorgar a la suerte la provisión de la mayoría de los cargos (no de todos) constituye un acto de fe en el sistema mismo y "en la virtud política de los ciudadanos” (Pl. R., 557a; Ath. 43; Olalla, 2015, p. 65). Por su parte, la elección, que en rigor implica un componente aristocrático, pues denota inclinación por lo mejor o el mejor (Arist. Pol. IV, 1300b4-5), está reservada para las funciones que demandan ciertas aptitudes naturales, una experiencia probada y no pocos recursos económicos. De ahí que electivos sean los cargos para la conducción de la guerra, el manejo de las finanzas públicas y los encargados de organizar las fiestas públicas (Ath. 43, 1).

No por ser procedimientos formales, el sorteo y la elección dejan de traducirse en realidades evidentes. Todo lo contrario. El registro histórico que elabora Aristóteles a lo largo de la primera parte de su tratado muestra que una gran cantidad de ciudadanos interviene sin más en el desempeño de alguna función pública. Dicha intervención, favorecida por la Liga ática creada en el 478/7 a. C., no es enteramente espontánea ni fruto de una disposición desinteresada. Si lo fue durante los inicios de la implementación del régimen, cuando la novedad de los nuevos derechos podía despertar en los atenienses una auténtica vocación democrática, la intervención en la vida comunitaria se torna después, si no influida por un aliciente inesperado, sí mediada por una previsión legislativa 
de la cual se sirve la ciudad para sufragar los servicios prestados: la provisión de la dieta pública o paga de salarios. Sea cual fuere la causa de esta medida (ora modificar la actitud de quienes alegan que nadie gobierna voluntariamente una ciudad sin recibir a cambio algún tipo de contraprestación -Pl. R. I, 345d-346a-, ora permitir que los más pobres y libres tengan acceso al gobierno), lo cierto es que Atenas financia la participación política sirviéndose de las rentas del Tesoro Público, el de Atenea y el Federal (Th. Hist. I, 80, 3). Ya que los salarios pagados por tal ejercicio no son elevados, pues hoy sabemos que los estipendios "no llegaban a la mitad del jornal mínimo" (Gil Fernández, 2009, p. 62; Jones, 1957, p. 135), la ciudad costea, cada año, la labor pública de más de veinte mil ciudadanos (Ath. 24, 3).

Pese a las duras críticas lanzadas por Pseudo-Jenofonte (o el Viejo Oligarca) contra la práctica ateniense de pagar en óbolos el desempeño de las funciones de gobierno, pues, a juicio suyo, muchos buscan los cargos solo por el sueldo que reciben y no por el provecho o asistencia que puedan brindar a los demás (Ps.X. Ath. I, 3-4), no existe evidencia documental que atribuya al pago de emolumentos la génesis de su ulterior decadencia. Si este fuera el caso, no se entendería por qué, iniciado el siglo IV a. C., la ciudad aprueba extender el pago de salario al dêmos que compone la Asamblea, con el propósito de que acuda "en número suficiente para [asegurar] la validez de la votación" (Ath. 41, 3).

La contemplación, o, mejor, el acto de ver y oír determina otro modo de participación en la vida cívica ateniense. Pero, ver y oír, ¿qué? Lo que, ni más ni menos, acontece en el Teatro, el edificio público erigido por Atenas para enaltecer a Dioniso, uno de los doce dioses de su panteón oficial. Ciertamente, la ciudad conmemora cada año, entre los días nueve y quince del mes de Elafebolión (el marzo-abril de nuestro calendario), la llegada de la deidad (o el advenimiento de la primavera), en el marco de unas fiestas llamadas Grandes Dionisias o Dionisias Urbanas (Lesky, 2001 [1957], p. 102; Simon, 1983, p. 55 y ss.). Dado el carácter radicalmente jovial de los atenienses, pues casi un tercio de su calendario lunar de 365 días se destina a la realización de celebraciones religiosas (Bruit y Schmitt, 2012, p. 81), las Grandes Dionisias se convierten en la ocasión propicia para 
que innumerables ciudadanos asistan, en calidad de espectadores, a un acontecimiento cultural: los certámenes dramáticos en los que concursan, sin duda impulsados por un espíritu agonal (herencia de los antiguos y venerables duelos heroicos cantados por Homero), entonadores de ditirambos, autores de trilogías trágicas -que se clausuran con un drama satírico- y comediógrafos. Sin perjuicio de su naturaleza ritual, puesta de relieve por el uso de máscaras teatrales, un lenguaje colmado de frases graves y sentenciosas y unos actores en quienes se delega la conducción de la acción ficticio-sacrificial, y fortalecido por el patronato de gentes acaudaladas -los coregas- a las cuales el arconte epónimo elige por sorteo para que costeen los gastos de los autores que desean participar en las justas poéticas (Ath. 56, 2-3), el drama, como género literario, llega a ser la creación artística mediante la cual los atenienses consiguen que la ciudad se procure a sí misma distintos esparcimientos que alejan la tristeza (Th. Hist. II, $38,1-4)$. Pero el teatro es mucho más que simple placer.

Una mayoría de varones asiste al teatro, no tanto para hacer uso del tiempo libre (noción esta que procede de la tradición judaica), cuanto para habérselas, en clave de ficción mimética, con un sinnúmero de asuntos de interés común: las vicisitudes de una deidad civilizatoria como Dioniso, las complejas motivaciones y consecuencias de la acción humana, la elaboración de la ley penal en el momento mismo de su trámite, la escurridiza y conflictiva noción de justicia, una severa crítica sobre cualquier clase de esencialismo moral, por no hablar "del espectáculo de la política representándose a sí misma” (Critchley, 2020, p. 82). En buena medida, el drama es financiado por la ciudad con el fin de que los atenienses, incluidos los más pobres a quienes se les otorga un subsidio de ingreso denominado theoricón (Ath. 43, 1; 47, 2), puedan contemplarse a sí mismos como ante un espejo (un "espejo roto", en palabras de Vidal Naquet, 2001, p. 53).

Agreguemos un último apunte sobre la participación: quien desempeña una función política, o una judicativo-teatral, ha de "jurar" (Winkler, 1992, p. 41). Para un ateniense, el juramento es un acto verbal al tiempo que gestual. Verbal, dado que implica proferir, ante sí mismo y otros ciudadanos, no cualquier tipo de palabras sino expresiones rituales de explícito contenido sacro; y gestual, puesto 
que supone acompañar las fórmulas emitidas con unos movimientos rituales, heredados de un pasado que se pierde en la noche de los tiempos. La promesa que subyace a la expresión ritual, además de incluir un contenido específico (decir la verdad, no ultrajar las leyes, aconsejar lo conveniente para la ciudad, etcétera), exige una formalidad adicional: poner por testigo a Zeus Horquio, dios de los juramentos. Por su parte, la acción gestual, ejecutada por los arcontes, consejeros, jueces y testigos, consiste en tocar con sus manos una piedra hierática que se erige en el altar exterior del Pórtico del rey y en repetir después la operación en el recinto de la Acrópolis (Ath. 7, 1; Pl. Euthd., 2a). Solo cuando el doble acto se realiza correctamente, la polis faculta a los ciudadanos para que den inicio a sus respectivos ministerios (Ath. 55, 5; X. Rec. I, 1, 18).

La potencia coactiva del juramento es vinculante, temible y onerosa. Vinculante, porque contribuye a refrenar la eventual comisión de su reverso, el perjurio; temible, porque el ciudadano, al invocar a Zeus como valedor divino, "firma su propia sentencia de muerte" (Longo, 2009, pp. 32-33), en caso de incumplir alguna de sus obligaciones; y onerosa, porque los arcontes, en particular, se obligan a ofrecer en Delfos una estatua en oro "equivalente en peso al de su propia persona” (Ath. 7, 1; Pl. Phdr., 235d; Plu. Sol., 25), allí donde sean sorprendidos en falta contra las leyes de la ciudad o cuando sean objeto de una acusación legalmente demostrada. Si la ciudad espera que todo magistrado y funcionario cívico actúe según la politiké areté, pues lo que está en juego es el surgimiento y consolidación de un nuevo "homo politicus" (Weber, 2005 [1944], p. 1035), vale anotar, un hombre que antepone los ideales democráticos a los viejos valores heroicos, entonces quien incumple el juramento, no haciendo lo debido, en el momento debido y del modo debido o, peor, haciendo lo indebido a sabiendas, y mofándose de la presunta sanción divina, "abdica de la propia areté, que impone la lealtad a los compromisos asumidos tanto ante los dioses como ante los hombres" (Longo, 2009, p. 33). 


\section{"Control"}

La antigua democracia ética, ¿es acaso una entidad históricopolítica, de suyo paradigmática? Las mudanzas constitucionales descritas por Aristóteles son una prueba fehaciente de que ningún gobierno es perfecto, no obstante ser la estabilidad el ideal de cualquiera de ellas (Arist. Pol. III, 1296a12-13; Cicerón, Rep. I, 45; Bobbio, 2006, p. 43). Ninguna constitución política admite el calificativo de perfecta, por la sencilla razón de ser una creación humana. La obviedad de esta formulación tal vez se atenúe un poco, si reparamos en el hecho de que son los atenienses los primeros en perfilar una semblanza del hombre cuyo contenido, sin dejar de responder a las determinaciones de una antropología local, supone un valor ético de alcance universal. Por definición ambivalente, pues se nutre de dos atributos que coexisten sin eliminarse recíprocamente, tal semblanza brota, como es sabido, de uno de los coros de Sófocles: "Muchas cosas asombrosas existen, y, con todo, nada más asombroso que el hombre" (Ant., vv. 332-333). Asombroso, a la par, porque posee "la destreza para ingeniar recursos", orientándolos a veces al bien, y porque, encaminando otras veces sus habilidades al mal, es capaz de cometer los peores ultrajes. Esa constante predisposición a la crueldad, que se manifiesta como contraparte del poder creativo humano, recibe el nombre genérico de hybris. Con ser que el término recubre varias acepciones, una se impone sobre las demás: la que nos hace saber de la posibilidad de la desmesura, de la falta de medida, en las palabras y acciones de los hombres. En la percepción ateniense que se plasma de manera discursiva tanto en géneros poéticos como en escritos en prosa, la hybris se despliega en múltiples gestos: es "el hartazgo [de autoridad] que engendra el abuso" (Solón, fr. 26, Ferraté, 2000, p. 79); es la deuda pagada por el gobernante "cuando la maldición del pueblo se cumple" (Esquilo, Ag., v. 458); es "el mal mayor de la anarquía" (Sófocles, Ant., v. 679); es el ensañamiento "con sus adversarios de quienes aspiran a los cargos" (Eurípides, Ion, v. 605); y es el provecho personal que se obtiene del ejercicio de las funciones públicas y por el cual muchos se empecinan en la aspiración de perpetuarse en el mando (Arist. Pol. III, 1278a1011). Omnipresente, impredecible, prolija, la hybris deja traslucir el 
rostro deplorable de la naturaleza humana. Su sombra se insinúa allí donde una empresa se pone en marcha, y no precisamente para desvelar los riesgos sino para incrementarlos, dado que ella representa la transgresión de límites que escapan a cualquier fijación explícita. Por emerger de las entrañas de los mortales, e impregnar de desenfreno cada una de sus iniciativas, la hybris difícilmente puede ser extirpada. Pese a lo cual, y a sabiendas de que no hay medio -ni siquiera "una norma de la norma"- que sea capaz de refrenar la aparición de una hybris individual o colectiva (Castoriadis, 2005, p. 116), la democracia ateniense no claudica en el empeño de establecer leyes cuyas intenciones están dirigidas menos a suprimir la potencia de desafuero que rebulle en los discursos y actos humanos que a controlarla por medio de la apelación a recursos legales.

A falta de "escuelas" de formación política en la Atenas del siglo $\mathrm{V}$ a. C., es la misma práctica civil, desdoblada año a año en la alternancia del mando y la obediencia (Arist. Pol. III, 1277a9-11), la que articula una paideia común justificada por la finalidad de robustecer la conciencia de la autonomía, la participación y el control políticos. Alejada en el tiempo de los valores y preceptos educativos fomentados por la aristocracia heroica (cultivar una sana emulación con el fin de ser siempre el primero entre hombres semejantes, exhibir una sed de honor insaciable, esforzarse al máximo en el campo de batalla para adquirir prestigio y reconocimiento sociales, etcétera), esta nueva paideia, gestada a impulsos de principios igualitarios, proclama el ideal del dominio de sí, de la templanza, del equilibrio (sophrosyne). Para los griegos, y en especial para los atenienses, dicho ideal, de cuño apolíneo, adquiere una significación tanto social como política. Ya que a menudo el poder no es más que una tensión entre opuestos animados, la sophrosyne,

haciendo desaparecer lo uno y lo otro, [puede contribuir a realizar] una ciudad armoniosa y concorde, donde los ricos, lejos de desear siempre más, dan a los pobres lo que les sobra, y donde la masa, lejos de sublevarse en rebeldía, acepta someterse a los que, por ser mejores, tienen derecho a poseer más (Vernant, 1972a, p. 102).

De ahí que, antes que ser una educación instrumental, encaminada a producir bienes materiales como los que fabrica el 
gremio de los artesanos, se trate más bien de una paideia concebida para nutrir el alma de la polis de bienes inmateriales, expresables bajo la forma positiva de una legislación, en la esperanza de que la ciudad, pese a estar atada a la ley del devenir y, por ende, a las vicisitudes propias de los ciclos naturales (Escobar, 2008, pp. 181-182), perdure en el tiempo y en el espacio el mayor tiempo posible. Una formación política comprometida con la virtud de la sophrosyne supone concebir la democracia, no como el régimen en el que los ciudadanos dan por sentado que nada ni nadie puede poner trabas a su libertad, sino como la forma de gobierno en la que "han de saber que no deben hacer cualquier cosa" (Castoriadis, 2005, p. 116), so pena de que la hybris se haga patente, ora bajo la figura de una confrontación civil, ora bajo la apariencia de un desastre militar o naval (como la desastrosa expedición a Sicilia, en el 415 a. C.), y dé al traste, momentánea o definitivamente, con el orden constitucional vigente.

Si el ideal de la sophrosyne exige de los ciudadanos una elevada disposición de autocontrol (en lo que atañe a sus deseos, intereses, acciones y palabras), y si, además, dicho ideal involucra una virtud política difícil de conquistar y, más, de poner en práctica una y otra vez ante circunstancias diferentes (Arist., EN II, 1109a25-30), entonces la ciudad, que se enorgullece de ser la única entre las poleis griegas de no tener por despreocupado sino por inútil a quien no toma parte en las funciones deliberativas y judiciales (Th. Hist. II, 40), termina por implementar un conjunto de dispositivos de control, enfocados a reforzar el horizonte de acción inherente a la educación política de cada uno de sus miembros. Cuando la intachable actuación política de un ciudadano hace innecesaria la aplicación de alguna medida de ajuste o vigilancia, la democracia griega intenta garantizar la buena marcha del sistema "mediante la existencia real de un control recíproco: el de cada ciudadano por el conjunto de ellos, y el del conjunto -es decir, el de la Polis- por cada ciudadano" (Olalla, 2015, p. 65). La persistencia de esta especie de mutua fiscalización, mediante la cual el régimen procura conjurar los posibles desmanes de los magistrados y demás funcionarios públicos (pretensión desmentida en la práctica, si tenemos en cuenta las multas y penas fijadas contra los culpables de incumplir o transgredir las leyes; Ath. 8, 5; 53, 
5), al parecer entraña la intención, no de explicitar las dudas que despierta un procedimiento como el del sorteo, sino de condicionar las acciones que un ciudadano puede realizar como consecuencia de este. Una vez la contingencia del sorteo se efectúa, brindando a la ciudadanía la oportunidad de participar en algunos de los cargos públicos, el sistema activa las medidas aprobadas para dar curso a la libre actuación política de los individuos y, por extensión, a todo el engranaje institucional.

Una técnica anular, envolvente, que se cierra sobre sí misma, asegura los términos de entrada y salida del grueso de los cargos públicos (esto es, de aquellos que se proveen por sorteo). El nombramiento de las magistraturas mayores (arconte epónimo, arconte rey y arconte polemarco) resulta ilustrativa a este respecto.

El proceso se abre con una suerte de "examen de aptitud", conocida como dokimasia (Ath. 55, 3-5). Descartado el requerimiento de la experiencia, innecesario en el marco de una forma de gobierno que prescribe la rotación anual de las legislaturas y que por ley otorga el derecho de participar a quien acredite la condición de ciudadano, según exponíamos arriba, el examen, realizado en principio por el Consejo de los Quinientos y luego por uno de los tribunales, consiste en comprobar, por un lado, la pertenencia del elegido a un linaje ateniense y a una circunscripción demótica (a uno de los más de cien "distritos" establecidos por la reforma de Clístenes), y, por otro, el cuidado puesto por el candidato en el cumplimiento de sus deberes como ciudadano: ser oficiante de ciertos cultos patrios -el de Apolo Paterno y el de Zeus Herceo, en cuanto dioses tutelares del Hogar de los atenienses-, pagar los impuestos, prestar el servicio militar e informar acerca de la cuantía y naturaleza del patrimonio personal (Ath. 7, 4). Tras esta fase, ejecutada mediante un interrogatorio puntual, las respuestas se contrastan con testimonios, a la espera de que alguien, si lo estima oportuno, ineludible o prudente, formule alguna clase de objeción. En caso de no presentarse esta, "la candidatura se somete a votación: a mano alzada en el Consejo y por voto secreto en un tribunal" (Ríos Ramírez y Fuentes Vélez, 2018, p. 97). En el ínterin, la ciudad espera del funcionario un cometido público sustentado menos en el deseo de prestación de un buen 
servicio, o en la exigencia de un uso racional de los recursos o en la expectativa de una actividad ejecutada con base en conocimientos especializados, que en la asunción y el cultivo del sentido del pudor o la vergüenza (aidós, del griego aitho, "arder"), concebida esta no solo como "el fuego interior que aflora en ocasiones en el rostro en forma de rubor" (Olalla, 2015, p. 78), sino también, y con mucho, como la valoración moral que el cuerpo cívico hace de la acción individual (Pl. Prt., 322c); pudor o vergüenza que, impregnada de una voluntad encaminada a conceder a cada quien lo que es conveniente o debido, se experimenta ante el otro y ante sí mismo.

Transcurrido el año de desempeño, el proceso termina con otra prueba, simétrica respecto de la primera, pero con un matiz evaluador diferente: ahora lo que se examina, bajo el nombre de euthynai ("rendición de cuentas"), es la probidad ética y económica de la función pública realizada. El magistrado que deja el cargo hace un doble balance de su gestión: el que atañe a sus bienes y el que concierne a la transparencia de su actuación (Ath. 54, 2; 56, 1). Y tal cosa ocurre ante los jueces presentes durante la dokimasia, al margen de que haya habido o no una acusación previa de malversación de fondos o de corrupción (Carawan, 1987, p. 190), o ante la ciudadanía misma, que puede o no estar de acuerdo con el juicio adelantado y solicitar una revisión del caso (Ríos Ramírez y Fuentes Vélez, 2018, p. 104).

Al ser el control político una especie de respuesta a la pregunta por los límites de la acción humana, Atenas establece, a partir de las reformas de Efialtes, entre otras medidas jurídicas (como la acusación de alta traición o eisangelía; Ath. 43, 4), una en especial tendiente a regular las proposiciones de ley cuya intención, en apariencia beneficiosa para la colectividad, después se revele contraria al interés común: la "acusación de ilegalidad" (graphé paránomos) (Ath. 29, 4; 45, 4; 59, 2).

Esquemáticamente, dicha medida puede ser descrita así: en virtud del principio de isegoría, un ciudadano $\mathrm{X}$ asiste a una de las cuarenta asambleas que se celebran al año, acepta tomar la palabra $y$, ante el pleno de sus paisanos, plantea una propuesta determinada. Si esta, tras un debate, recibe el aval de la mayoría, la Asamblea 
la acoge y procede a convertirla en ley. Pasado un tiempo, en plazos sobre los que no se tiene una información muy precisa, un ciudadano Y, perteneciente a otra de las tribus clistenianas, se atreve a denunciar, ante uno de los tribunales, al ciudadano X. ¿La razón? Quiere probar que la proposición aprobada por la Asamblea atentó contra el bienestar de todos. Dicho en breve, "se acusa al nómos de ser paránomos, a la ley de ser ilegal” (Castoriadis, 2012, p. 163). Se conforma, entonces, un tribunal para que estudie la solicitud. En caso de no ser procedente la acusación, el inculpado es absuelto; pero si, al revés, se valora conforme a derecho y su contenido se interpreta como perjudicial para la ciudad, la acusación acarrea dos consecuencias: (a) la ley es derogada en el acto, pese a haber sido votada y aprobada por la Asamblea; y (b) el proponente se convierte "en reo del crimen de ilegalidad", lo que de inmediato lo hace acreedor de una pena que va "desde una simple sanción económica [...] hasta la privación de los derechos políticos" (Hansen, 2009, pp. 241-243; Olalla, 2015, p. 55). Mediante esta medida, pues, el dêmos se educa políticamente a sí mismo: por derecho, cualquier ciudadano tiene la libertad de proponer lo que crea oportuno, razonable y provechoso para la mancomunidad, pero -dado el curso que toma esta clase de iniciativa- ha de reflexionar dos veces antes de pasar a la acción y así evitar ser objeto de juzgamiento por el mismo cuerpo de ciudadanos al cual dirige su proposición. La inferencia admite ser enunciada de este modo: "[E]l pueblo dicta la ley, el pueblo se puede equivocar, el pueblo se puede corregir. He aquí un magnífico ejemplo de una institución eficaz de autolimitación" (Castoriadis, 2005, p. 119).

Puesto que decir democracia equivale a autorizar el uso público de la palabra, pero no el empleo de una violencia sorda como instrumento de poder, y puesto que, en la Atenas del siglo v a. C., dicha palabra "llega a ser [...] la llave de toda autoridad en el Estado, el medio de mando y de dominación sobre los demás", hasta el punto de que los ciudadanos hacen de ella, de su energía y eficacia de persuasión, una deidad denominada Peithó (Vernant, 1972a, pp. 6162), la ciudad se protege de ciertas clases de abuso verbal, espontáneas algunas y deliberadas otras, implementando una serie de medidas encaminadas a producir una equilibrada ligazón entre el ejercicio 
de la política y el despliegue del arte oratorio. Y tal equilibrio se busca, sobre todo, aunque de manera diferente, en los ámbitos de participación forense y deliberativo.

En el primero, desarrollado en los Tribunales de Justicia, es la forma de los procedimientos, y no la materia de las causas jurídicas, la que avala la armonía entre los dos elementos señalados; en el segundo, llevado a cabo en la Asamblea, el asunto funciona al revés. Por eso, quien entable querella ante un tribunal, bien como acusador, bien como defensor (acusación y defensa que pueden contar con los servicios de logógrafos de oficio), ha de saber, dado que así lo estipula la ley, que ha de contar con un tiempo de alocución limitado, cuya duración es indicada por un reloj de agua (clepsidra) y controlada por funcionarios elegidos por sorteo, para tramitar su querella (Ath. 67, 2). Con el objeto de evitar que el demandante o el demandado se excedan en su elocuencia, y obtengan algún tipo de ventaja, la práctica forense, en cuanto discurso en acto, supedita la participación pública al factor temporal. De ahí que los litigios largos, y largos serían aquellos que implicaran un día de duración (X. HG I, 7, 20-30), constituyan la excepción. Por su parte, quien intervenga como orador en la Asamblea, ya porque ha contado con una preparación retórica previa impartida por alguno de los sofistas que gustan de visitar la ciudad (Guthrie, 1995, p. 77), ya porque ha logrado vencer la vergüenza, la vacilación y el temor que supone hablar ante miles de individuos reunidos en un mismo espacio (X. Rec. III, 7), ha de saber que, cualquier sea el tiempo de duración de su discurso, el contenido de este debe plegarse a la verdad y sinceridad de lo dicho, so pena de que el mismo dêmos descubra que está siendo engañado y levante contra él, conforme a la ley, una acusación grave denominada "de engaño contra el pueblo" (apaté tou demou), en cuyo caso la ciudad lo obliga a comparecer ante los tribunales.

Aparte de estas figuras jurídicas, la democracia ática conoce, por ser una institución creada por Clístenes, y pone en práctica, por vez primera en la persona de un tal "Hiparco, hijo de Carmo, del demo de Colito" (Ath. 22, 1-4), otra medida de control encaminada a salvaguardar el sistema político contra posibles focos de perturbación interna. Afincada en el principio de igualdad, la medida, llamada 
ostracismo (derivado de ostraka: "pedazo de vasija rota”), busca inhibir todo asomo, voluntario o involuntario, de desigualdad. Y, para la ciudad, la desigualdad brota y se impone cuando un ciudadano comienza a destacarse en exceso sobre los demás. Conforme se consolidan los ideales democráticos, la ciudad no ve con buenos ojos que alguien sobresalga por su poder, sus riquezas, sus muchas relaciones o "por cualquiera otra fuerza política" (Arist. Pol. III, $1284 \mathrm{a}_{15-17}$ ), pues tal hecho despierta no solo desconfianza, sino también preocupación. Desconfianza, porque suscita una serie de habladurías cuya imparable dinámica atenta -o puede atentarcontra la armonía civil; y preocupación, porque introduce un factor de desequilibrio social allí donde se quiere implantar una situación de unidad colectiva. En consecuencia, la ciudad (representada inicialmente por los miembros de la sexta pritanía, en la que se estima si cabe darle lugar al ostracismo, y luego en la octava donde se fija un día para proceder a la votación masiva; Ath. 43, 5), toma la decisión de desterrar, por espacio de diez años, a aquel cuyo nombre queda escrito en los trozos de cerámica el mayor número de veces, respecto de un quórum de 6000 posibles votantes. Y, ¿por qué se lo expulsa como si se tratara de un phármakos o "chivo expiatorio"? ¿Acaso porque ha cometido algún crimen? De ninguna manera. La mancomunidad lo hace marchar de la ciudad, sin posibilidad de que pueda apelar la decisión, simple y llanamente porque lo considera un peligro para la estabilidad del cuerpo cívico. La idea es que este a quien la Fortuna ha sonreído en demasía, que se ha elevado sobremanera y "que domina desde una altura demasiado grande [...] traerá alguna calamidad. Así, se le expulsa, y remarcablemente, la institución especifica que no se da ninguna razón para su expulsión" (Vernant, 1972b, pp. 299-300).

Finalmente, la acusación de "engaño contra el pueblo", instrumento esencial de los demagogos (que no de los caudillos de pueblo), consiste en persuadir al dêmos, mediante el empleo de técnicas retóricas (basadas menos en argumentos razonables tendientes a la búsqueda y establecimiento de la verdad que en opiniones falaces tendientes a producir la ilusión de lo verdadero), de que los yerros o equivocaciones cometidos por la Asamblea son imputables menos a 
la multitud misma que a la retórica engañosa de los oradores. A este respecto, no sobra indicar una situación polémica: si, en últimas, el dêmos es el depositario de la soberanía política, pues no en vano es la instancia que ejerce el máximo control y vigilancia sobre la totalidad de las magistraturas públicas, ¿cuál es, por así decirlo, el órgano constitucional que, estando por encima del dêmos, puede llevar a cabo un control sobre él? La respuesta es negativa, y la brinda Gil Fernández: no hay tal órgano, nadie tiene la potestad de controlar al dêmos; de ahí que a este no se le pueda endilgar responsabilidad alguna (2011, p. 72).

He aquí, ni más ni menos, la más grande imperfección de este sistema ateniense. Esto es justamente lo que el Viejo Oligarca ya denunciaba en su letal opúsculo contra el régimen político de los atenienses:

[...] de cuanto el pueblo acuerda puede negar responsabilidad a los demás cargándola sólo en el que interviene y propone la votación [...] Y si resulta algún perjuicio de las decisiones del pueblo, éste aduce que unos pocos individuos actuaron en contra suya y lo echaron a perder. En cambio, si resulta algún bien, se atribuyen la causa a sí mismos (Ps.X. Ath. 2, 17).

\section{Conclusiones}

Ensayemos, si no a concluir, a cerrar estas reflexiones. Gracias a un golpe de suerte arqueológico, que sacó de las arenas de Egipto un número apreciable de papiros, hoy podemos leer el texto que Aristóteles escribió para informar acerca de la historia constitucional de los atenienses. Dicha historia, larga en el tiempo, revela un dinamismo político marcado por más de una decena de cambios de formas de gobierno. Múltiples causas (tensión social entre ricos y pobres, ambición de poder de ciertos individuos, declaraciones de guerra, miedos colectivos, etcétera) llevan a Atenas a adoptar formas de gobierno diferentes.

Una en especial, iniciada por Solón, potenciada por Clístenes y radicalizada por Efialtes y Pericles (Benéitez, 2005, p. 42), perdurará durante décadas: el gobierno democrático. Su permanencia en el tiempo, conseguida no sin resistencias y oposiciones por parte del minoritario pero poderoso estamento de los oligarcas -revolución de los Cuatrocientos en el 411 a. C. y la Tiranía de los Treinta y 
de los Diez en los años 404/403 a. C.-, procede de un hecho nunca antes experimentado por Atenas: el poder, en cuanto facultad para gobernar, deja de ser prerrogativa de unos pocos (a menudo poseedores de una riqueza heredada) y pasa a ser potestativo de muchos (aún de los que, siendo libres, carecen de suficientes bienes de fortuna).

Pese a que la democracia no nace cuando irrumpe la ciudad, es difícil que aquella se hubiera dado sin el desarrollo tecnológico, económico y social de esta. En la captación griega, y en particular la ateniense, la ciudad no es un área geográfica amurallada, aunque, desde luego, reclama un espacio propio o apropiado (Pl. R. II, 569c); no son tampoco las instituciones que legitiman la creación de un cierto ordenamiento cívico, con ser que sin ellas apenas tendría sentido hablar de espacio y tiempo públicos; y menos son los mecanismos con base en los cuales las instituciones encuentran su razón de ser, y sin cuyo concurso sobraría la idea de funcionamiento administrativo. Para los atenienses, en una palabra, la polis son los hombres y, sobre todo, los ciudadanos que comprenden que, aparte de una forma de vida propia, existe otra que es incluso más significativa, dado que es fuente de realizaciones colectivas ejecutadas a través de la palabra y la razón y no de la violencia bruta: la forma de la vida comunitaria (koinonía). Gracias a esta vida política, los atenienses, amantes y defensores a ultranza de la libertad, toman conciencia de la necesidad de contar con independencia política o, mejor, con jurisdicción soberana para hacer sus propias leyes, juzgarse a sí mismos y ser agentes y pacientes de un gobierno autónomo.

El poder de la colectividad, amparado en el otorgamiento de ciertos derechos -isegoría, isopsephia y parresía- a los campesinos y artesanos (ese amplio conglomerado sin cuya labor productiva la ciudad escasamente podría sobrevivir), se traduce en una realidad política, la de la participación en las principales instituciones de gobierno, militares y culturales, cuya eficacia presupone el cumplimiento de un único requisito: la acreditación de la ciudadanía. La participación ciudadana, antes que expresarse a través de delegados locales, se plasma en la palabra y la acción o, si se prefiere, en el voto de aquellos que intervienen directamente en los asuntos comunes. Intervención cimentada en la premisa de que no existe 
un saber político especializado (como sí lo hay en otros ámbitos de acción en los que la adquisición y el uso de una técnica es garantía de producción de una obra útil y bella), y regulada por el acatamiento de la norma que prescribe que cualquier cargo público no puede exceder un año de servicio; a lo cual se le suma la observancia de la disposición que establece que, salvo las magistraturas que atañen al manejo de las finanzas de la ciudad y al arte de la guerra, el resto de las funciones que dan cuerpo a la vida política son producto del sorteo y nada más que del sorteo. Al ocuparse voluntariamente del destino de ciudad (no sin el estímulo del pago de un salario), el dêmos se convierte en el agente de creación de una paideia política cuya sustancia de contenido se resume en la consecución de un aprendizaje mancomunado: el de saber gobernar y ser gobernado. Por último, la ciudad, por medio de su sistema institucional, elabora mecanismos de "control y vigilancia" con el fin de sofrenar la hybris o desmesura que rebulle en todo acto humano $\mathbb{C}$

\section{Referencias}

Arendt, H. (2006). La condición humana (R. Gil Novales, Trad.). Paidós.

Aristóteles. (1988). Política (M. García Valdés, Trad.). Gredos.

Aristóteles. (1998). Constitución de los atenienses [Ath.] (M. García Valdés, Trad.). Gredos.

Aristóteles. (2003). Ética Nicomáquea - Ética Eudemia (Intr. E. Lledó Iñigo; Trad. y notas de J. Palli Bonet). Gredos.

Aristóteles. (2003). Retórica (A. Tovar, Ed.). Centro de Estudios Políticos y Constitucionales.

Barahona, P. (2008). Historia de Grecia: Día a día en la Grecia Clásica. Libsa.

Beneítez, B. (2005). La ciudadanía de la democracia ateniense. Foro Interno, (5), 37-58. https://bit.ly/3FUKObN

Berti, E. (2012). Aristóteles (H. Aguilá Ruzola, Trad.). Gredos.

Bianchi Bandinelli, R. (1981). Del Helenismo a la Edad Media. Akal. 
Bobbio, N. (2006). La teoría de las formas de gobierno en la historia del pensamiento político (J. F. Fernández Santillán, Trad.). Fondo de Cultura Económica.

Bruit Zaidman, L. y Schmitt Pantel, P. (2012 [1989]). La religión griega en la polis de la época clásica (M. de F. Díez Platas, Trad.). Akal.

Carawan, E. M (1987). Eisangelia and Euthyna: The Trial of Miltiades, Temistocles and Cimo. Greek, Roman and Byzantine Studies, 28(2), 167-208. https://grbs.library.duke.edu/article/view/4761

Castoriadis, C. (2005). Escritos políticos (X. Pedrol, Trad.). Los Libros de la Catarata.

Castoriadis, C. (2012). La ciudad y las leyes. Lo que hace a Grecia, 2. Seminarios 1983-1984. La creación humana III (H. Pons, Trad.). Fondo de Cultura Económica.

Cicerón, M. T. (1998). Sobre la república (Intr., trad., apéndice y notas de Á. D’Ors). Gredos.

Crane, G. R. (s. f). Perseus Digital Library. Tufts University. http://www. perseus.tufts.edu/hopper/

Critchley, S. (2020). La tragedia, los griegos y nosotros (D. López González, Trad.). Turner.

Cruz Vélez, D. (2014). El mito del rey filósofo. Universidad Nacional de Colombia, Universidad de los Andes, Universidad de Caldas.

De Romilly, J. (2004). La ley en la Grecia clásica (G. Potente, Trad.). Biblos, Deseo de Ley.

Detienne, M. (2004 [1967]). Los maestros de la verdad en la Grecia arcaica (J. J. Herrera, Trad.). Sexto piso.

Diógenes Laercio [D.L.]. (2007). Vidas y opiniones de los filósofos ilustres (Trad., intr. y notas de C. García Gual). Alianza.

Escobar Moncada, J. (2008). Justicia y vida buena en Platón. En E. Domínguez Gómez (Comp.), Historia de las ideologías políticas: Proyecto Ágora (pp. 179-199). Fondo Editorial Universidad EAFIT.

Esquilo. (2000). Tragedias (Intr. F. Rodríguez Adrados; trad. y notas de B. Perea Morales). Gredos. 
Eurípides. (2000). Tragedias I. Alcestis; Medea; Los Heráclidas; Hipólito; Andrómaca; Hécuba (Intr. grl. C. García Gual; intr., trad. y notas de A. Medina González y J. A. López Férez). Gredos.

Eurípides. (2000). Tragedias. II. Heracles; Ion; Las troyanas; Electra; Ifigenia entre los Tauros (Intr., trad. y notas de J. L. Calvo Martínez). Gredos.

Ezquerra Gómez, J. (2009). Pólis y Caos. El espacio de lo político. Res Publica, (21), 21-37. https://revistas.ucm.es/index.php/RPUB/article/ view/46038

Ferraté, J. (2000). Líricos griegos arcaicos. Acantilado.

Foucault, M. (2004). Discurso y verdad en la antigua Grecia (Intr. Á. Gabilondo y F. Fuentes Megías; trad. F. Fuentes Megías). Paidós.

García Gual, C. (2007). Encuentros heroicos: Seis escenas griegas. Fondo de Cultura Económica.

García Moreno, L. A. (2008). El establecimiento de la democracia ateniense: igualdad y libertad. En L. A. García Moreno y G. Tortella (Eds.), La democracia ayer y hoy (pp. 73-100). Gadir.

Gil Fernández, L. (2011). Sobre la democracia ateniense. Dykinson.

González Ochoa, C. (2004). La polis: Ensayo sobre el concepto de ciudad en la Grecia antigua. Universidad Nacional Autónoma de México.

Guthrie, W. K. C. (1995 [1958]). Los filósofos griegos (F. M. Torner, Trad.). Fondo de Cultura Económica.

Guthrie, W. K. C. (2003 [1962]). Historia de la filosofía, III (J. Rodríguez Feo, Trad.). Gredos.

Hall, E. (2020). Los griegos antiguos: Las diez maneras en que modelaron el mundo moderno (D. Najmías Bentotila, Trad.). Anagrama.

Hansen, M. H. (2009). La Démocratie athénienne á l'époque de Démosthène: Structure, principes et idéologie. Tallandier.

Hansen, M. H. \& Nielsen, T. (2004). An Inventory of Archaic and Classical Poleis. Oxford University Press.

Hanson, V. D. (2006). Matanza y cultura: Batallas decisivas en el auge de la civilización occidental (A. Diéguez Rodríguez, Trad.). Fondo de Cultura Económica. 
Heródoto [Hdt.]. (2008). Historia [Hist.] (Intr. F. Rodríguez Adrados; trad y notas de C. Shrader). Gredos.

Homero. (2000). Odisea (Intr. C. García Gual; trad. J. Manuel Pabón). Gredos.

Homero. (2007). Ilíada (Trad., pról. y notas de E. Crespo Güemes). Gredos.

Isócrates. (1998). Panegírico [Pan.] Discursos (Trad. y notas de J. M. Guzmán). Planeta DeAgostini.

Jaeger, W. (2008 [1934]). Paideia: Los ideales de la cultura griega (2. ${ }^{a}$ ed., J. Xirau y W. Roces, Trads.). Fondo de Cultura Económica.

Jenofonte [X.]. (1993a). Recuerdos de Sócrates [Rec.]. Banquete. Apología de Sócrates (Intr., trad. y notas de J. Zaragoza). Planeta DeAgostini.

Jenofonte [X.]. (1993b). Económico [Oec.] (Intr., trad. y notas de J. Zaragoza). Gredos.

Jenofonte [X.]. (2000). Helénicas [HG] (Intr. J. Gómez Espelosín; trad. y notas de O. Guntiñas Tuñón). Gredos.

Jones, A. H. M. (1957). Athenian Democracy. The Johns Hopkins University Press.

Lane Fox, R. (2007). El mundo clásico: La epopeya de Grecia y Roma (J. Rabasseda y T. de Lozoya, Trads.). Crítica.

Lesky, A. (2001 [1957]). La tragedia griega (J. Godó Costa, Trad.). Acantilado.

Liddell, H. G. \& Scott, R. (1953). Greek-English Lexicon. Oxford University Press.

Longo, O. (2009). El universo de los griegos: Actualidad y distancias (S. Mastrangelo, Trad.). Acantilado.

Martínez García, O. (2015). Héroes que miran a los ojos de los dioses: La historia de Grecia desde la Edad de Bronce hasta el final de la Época Clásica. Edaf.

Mosse, C. (1987). Historia de una democracia: Atenas. Akal.

Olalla, P. (2015). Grecia en el aire: Herencias y desafíos de la antigua democracia ateniense vistos desde la Atenas actual. Acantilado.

Píndaro (2002). Odas y fragmentos. Olímpicas; Píticas; Nemeas; Fragmentos (Intr. E. Ruiz Yamuza; trad. y notas de A. Ortega). Gredos. 
Platón [Pl.]. (1981). Critón [Crit.]; Protágoras [Prt.]. En Diálogos I. Apología; Critón; Eutifrón; Ion; Lisis; Cármides; Hipias Menor; Hipias mayor; Laques; Protágoras (Intr. E. Lledó; trad. y notas de J. Calonge, E. Lledó y C. García Gual). Gredos.

Platón. (1983). Diálogos II. Gorgias [Grg.]; Menéxeno; Eutidemo; Menón; Crátilo (Trad., intr. y notas de J. Calonge Ruiz, E. Acosta Méndez, F. J. Olivieri y J. L. Calvo). Gredos.

Platón. (1988). Teeteto [Tht.]. En Diálogos V. Parménides; Teeteto; Sofista; Político (Trad., intr. y notas de M. I. Santa Cruz, Á. Vallejo Campos y N. L. Cordero). Gredos.

Platón. (1994). El Político (Intr., trad. y notas de A. González Laso). Critón (Intr., trad. y notas de M. Rico Gómez). Menón (Intr., trad. y notas de A. Ruiz de Elvira). Centro de Estudios Constitucionales.

Platón. (2006a). Diálogos VIII. Leyes (libros I-VI) (Intr., trad. y notas de F. Lisi). Gredos.

Platón. (2006b). República [R.] (J. M. Pabón y M. Fernández-Galiano, Trads.). Centro de Estudios Constitucionales.

Plutarco [Plu.]. (2008). Vidas Paralelas. Solon [Sol.]; Publícola; Temístocles; Camilo; Pericles; Fabio Máximo (Trad. y notas de A. Pérez Jiménez). Gredos.

Pseudo-Jenofonte [Ps.X.]. (1984). La república de los atenienses [Ath.] (Intr., trad. y notas de O. Guntiñas Tuñon). Gredos.

Ríos Ramírez, A. y Fuentes Vélez, L. (2018). Democracia, control político y rendición de cuentas. Co-herencia, 15(28), 87-109. https://doi. org/10.17230/co-herencia.15.28.4

Rodríguez Adrados, F. (1998). La democracia ateniense. Alianza.

Rodríguez Adrados, F. (2008). Democracia antigua y moderna. En L. A. García Moreno y G. Tortella (Eds.), La democracia ayer y hoy (pp. 35-51). Gadir.

Rodríguez Adrados, F. (2011). Nueva historia de la democracia: De Solón a nuestros días. Ariel.

Simon, E. (1983). Festivals of Athica: An archaeological Commentary. The University of Wisconsin Press. 
Sinclair, R. K. (1999). Democracia y participación en Atenas (J. Ferraré, Trad.). Alianza.

Sófocles. (2001). Tragedias (Intr. J. Bergua Cavero; trad. y notas de A. Alamillo). Gredos.

Tovar, A. (2000). Introducción. En Aristóteles, Constitución de Atenas. Centro de Estudios Políticos y Constitucionales.

Tucídides [Th.]. (1999). Historia de la Guerra del Peloponeso (J. J. Torres Esbarranch, Trad.). Planeta De Agostini.

Vernant, J-P (1972a). Los orígenes del pensamiento griego (M. Ayerra Redín, Trad.). Paidós.

Vernant, J-P. (1972b). La tragedia griega: problemas de interpretación. En R. Macksey y E. Donato (Eds.), Los lenguajes críticos y las ciencias del hombre: Controversia estructuralista (pp. 295-317). Barral.

Vernant, J-P. (1973). Mito y pensamiento en la Grecia antigua (J. D. López Bonillo, Trad.). Siglo XXI.

Vernant, J-P. (2008). Atravesar fronteras: Entre mito y política II (H. F. Bauzá, Trad.). Fondo de Cultura Económica.

Vidal-Naquet, P. (2001). El espejo roto: Tragedia y política en la Grecia antigua (M. Llinares García, Trad.). Abadá.

Weber, M. (2005 [1944]). Economía y sociedad. Fondo de Cultura Económica.

Winkler, J. J. (1992). The Ephebes' Song: Tragôidia and Polis. En J. J. Winkler \& F. I. Zeitlin (Eds.), Nothing to Do with Dionysos? Athenian Drama in Its Social Context (pp. 20-62). Princeton University Press. 